\title{
MUSEUM PEDAGOGY IN EDUCATION: EDUCATIONAL, HISTORICAL, AND PEDAGOGICAL ASPECTS
}

\author{
PEDAGOGIA DE MUSEUS NA EDUCAÇÃO: ASPECTOS EDUCACIONAIS, \\ HISTÓRICOS E PEDAGÓGICOS
}

\section{LA PEDAGOGÍA DEL MUSEO EN LA EDUCACIÓN: ASPECTOS EDUCATIVOS, HISTÓRICOS Y PEDAGÓGICOS}

\author{
Filipchuk NATALIIA ${ }^{1}$ \\ Kvasetska YARINA ${ }^{2}$ \\ Bazyl LUDMILA ${ }^{3}$ \\ Orlov VALERIY ${ }^{4}$ \\ Vovk MYROSLAVA ${ }^{5}$ \\ Zahaiska GALINA $^{6}$
}

\begin{abstract}
At the present stage of civilizational development, characterized by numerous transformations in the historical-political, socio-economic, cultural, scientific, and educational spheres of social progress, the importance of using the results of pedagogical innovation in continuing education is emphasized. The study's aim is to consider the experience of using museum pedagogy based on education and analyzes this phenomenon in terms of historical and pedagogical aspects. To meet the objective of the study, the descriptive method is utilized. Based on the results obtained, it can be concluded that the mission of museums is to increase the level of knowledge and moral and spiritual education. The authors state that the priority approach of the state cultural, scientific, and educational policy should be the effective use of museum activities for the public good. Education requires the active introduction of museum pedagogy to improve the educational process.
\end{abstract}

KEYWORDS: Museum. Pedagogy. Education. Pedagogical aspects. Innovation.

${ }^{1}$ Ivan Ziaziun Institute of Pedagogical Education and Adult Education of the National Academy of Pedagogical Sciences of Ukraine, Kyiv - Ukraine. Senior Researcher and Leading Researcher of the Department of Pedagogical Education Content and Technology. PhD in Pedagogy. ORCID: https://orcid.org/0000-0002-6274-9792. E-mail: filipchukn1@yahoo.com

${ }^{2}$ Yurii Fedkovych Chernivtsi National University, Chernivtsi - Ukraine. Assistant of the Department of Pedagogy and Psychology of Preschool Education. PhD in Pedagogy. ORCID: https://orcid.org/0000-0002-3121-6264. Email: kvasetska.ya@yahoo.com

${ }^{3}$ Institute of Vocational Education and Training of the National Academy of Pedagogical Sciences of Ukraine, Kyiv - Ukraine. Associate Professor and Academic Secretary. Doctor of Science in Pedagogy. ORCID: https://orcid.org/0000-0003-1842-1535. E-mail: bazyll1123@yahoo.com

${ }^{4}$ Institute of Vocational Education and Training of the National Academy of Pedagogical Sciences of Ukraine, Kyiv - Ukraine. Professor and Senior Research Fellow of Professional Career Laboratory. Doctor of Science in Pedagogy. ORCID: https://orcid.org/0000-0003-1776-7710.E-mail: orlov.v1@yahoo.com

${ }^{5}$ Ivan Ziaziun Institute of Pedagogical Education and Adult Education of the National Academy of Pedagogical Sciences of Ukraine, Kyiv - Ukraine. Senior Researcher and Head of the Department of Pedagogical Education Content and Technology. Doctor of Science in Pedagogy. ORCID: https://orcid.org/0000-0002-1761-9198. Email: vovk.mm@yahoo.com

${ }^{6}$ Yurii Fedkovych Chernivtsi National University, Chernivtsi - Ukraine. Associate Professor and Head of the Department of Romanian and Classical Philology. PhD in Philology. ORCID: https://orcid.org/0000-0003-48623939. E-mail: zahaiskah@gmail.com

RPGE- Revista on line de Política e Gestão Educacional, Araraquara, v. 25, n. esp. 3, p. 1844-1859, Sep. 2021. e-ISSN: 1519-9029 
RESUMO: No atual estágio de desenvolvimento civilizacional, caracterizado por inúmeras transformações nas esferas histórico-políticas, socioeconômicas, culturais, científicas e educacionais do progresso social, destaca-se a importância de utilizar os resultados da inovação pedagógica na formação continuada. O objetivo do estudo é considerar a experiência de utilização da pedagogia museológica a partir da educação e analisar esse fenômeno do ponto de vista histórico e pedagógico. Para atender ao objetivo do estudo, é utilizado o método descritivo. Com base nos resultados obtidos, pode-se concluir que a missão dos museus é elevar o nível de conhecimento e educação moral e espiritual. Os autores afirmam que a abordagem prioritária da política cultural, científica e educacional estadual deve ser o uso efetivo das atividades museológicas para o bem público. A educação requer a introdução ativa da pedagogia de museus para melhorar o processo educacional.

PALAVRAS-CHAVE: Museu. Pedagogia. Educação. Aspectos pedagógicos. Inovação.

RESUMEN: En la etapa actual de desarrollo civilizatorio, caracterizada por numerosas transformaciones en las esferas histórico-política, socioeconómica, cultural, científica y educativa del progreso social, se enfatiza la importancia de utilizar los resultados de la innovación pedagógica en la educación continua. El objetivo del estudio es considerar la experiencia de utilizar la pedagogía de los museos desde la educación y analizar este fenómeno en términos de aspectos históricos y pedagógicos. Para cumplir con el objetivo del estudio se utiliza el método descriptivo. Con base en los resultados obtenidos, se puede concluir que la misión de los museos es incrementar el nivel de conocimiento y educación moral y espiritual. Los autores afirman que el enfoque prioritario de la política estatal cultural, cientifica y educativa debe ser el uso efectivo de las actividades del museo para el bien público. La educación requiere la introducción activa de la pedagogía de los museos para mejorar el proceso educativo.

PALABRAS CLAVE: Museo. Pedagogia. Educación. Aspectos pedagógicos. Innovación.

\section{Introduction}

Pedagogical science and its subdisciplines pay particular attention to studying and using the potential of humanistic, democratic, and cultural values in educational practice. The key characteristic of educational processes has become the large-scale application of applied pedagogical technologies. The realization of tendencies of culturology, hermeneutics, interdisciplinarity in continuing education, technologies of research, integrated, practiceoriented, project, imitation-role, contextual learning is becoming more and more widespread. The education sector is gradually being transformed into a continuously self-developing and complexly structured system, which ensures the diverse development of citizens and appears as a cultural process. In this regard, the study of the peculiarities of applying elements of museum pedagogy in educational practice becomes especially important. The appeal of teachers-practitioners to the educational function of museums makes it possible to implement 
the "interdisciplinary revolution", thus creating favorable conditions for educational, research, project, social and adaptive activities.

\section{Literature Review}

The theoretical framework of museum pedagogy is still being defined. It is a practical necessity and today there is objective knowledge of the laws of its development, interdisciplinary connections, the establishment of the scientific apparatus (KAMINSKA, 2013).

The main areas of research in the field of museum pedagogy can be structured as follows:

1. The problem of studying the educational specifics of the museum.

2. The effectiveness of museum communication.

3. The study of the museum audience.

4. The creation and implementation of new methods, programs and expositions for different categories of the population.

5. The establishment of optimal forms of interaction with partners for cultural and educational activities.

6. The use and promotion of new educational technologies.

Defining the main ways of reforming education at the beginning of our Independence, the State National Program "Education" Ukraine of the $21^{\text {st }}$ century stressed the need to "overcome the devaluation of universal humanistic values and national nihilism, isolation from national sources", and the national orientation of education is inseparable soil, its organic combination with national history and folk traditions, preservation and enrichment of the culture of the Ukrainian people (State National Program "Education" Ukraine of the $21^{\text {st }}$ century, 1994). Although many productive steps have been taken in the implementation of these socially significant tasks in the political, scientific, organizational, pedagogical, educational and methodological spheres, several important cultural and educational issues, insufficient efforts of the state, civil society, scientific, and educational institutions for the education of a nationally conscious and patriotic Ukrainian community have been addressed.

Museum pedagogy is gradually expanding the circle of supporters and practitioners among educators in Ukraine. However, this process is slow and with minimal effect since there is no system for defining, developing and implementing museum pedagogy in the national educational space (DUDAR, 2016). The first country in the world to recognize the profession 
of "museum educator" was the United States. There, specialists of the appropriate level are trained in three higher educational institutions: at the University of J. Washington in Washington, D.C., at Bank Street College in New York, at the University of California, Los Angeles.

It is necessary to intensify the productive interaction of the museum with educational institutions of different levels, although teachers mostly perceive cooperation with the museum passively traditionally, for example, as a regular tour. This indicates the need to modernize not only the work of the museum but also to train teachers who can think outside the box, effectively model the learning environment through museum pedagogy to increase the level of learning and integration of knowledge from different fields by their students. The "new vision" of the role of museums involves organizing cooperation that will positively affect the development of the younger generation. It is important that the level of competence of visitors and the understanding of the value of museums in the world, within numerous communities, increase. The museum should be perceived not only as a place of preservation of traditional cultural values but also as an environment for quality learning (BELOFASTOVA, 2013). During the museum-pedagogical dialogue, there is an opportunity to demonstrate how work the process of searching and interpreting information about each museum exhibit, the individual features and properties of the historical monument affect the understanding of the exhibit, and how to work with the museum exhibit to increase its emotional impact (DUDAR, 2016).

\section{Materials and Methods}

The study of scientific publications on museum pedagogy in Ukraine shows that even though researchers insufficiently analyze foreign sources, they convincingly substantiate the process of developing museum pedagogy as an innovative field. This concept was introduced into scientific use in Germany in 1934. However, the foundations of museum activities as an area of education and training of young people began to be laid in the early $20^{\text {th }}$ century, and a new field of knowledge and research has begun to be established since the 1950s, "museums had to significantly expand their functions and traditional activities, which meant to intensify their participation in society, to integrate into a specific socio-cultural environment" (FILIPCHUK, 2018, p. 138).

The spread and constant improvement of advanced educational technologies in the modern "knowledge society" causes global changes in the ways of communication and interaction between people. In particular, it concerns the organization of a high-quality, efficient 
and dynamic learning process in schools and universities, which does not cause resistance or lead to stressful situations and conflicts but causes joy and satisfaction, optimistic perception of life and other people. Teachers around the world are faced with a dilemma: how to prepare professionals ready for significant social and economic changes, competitive market conditions, responsible decision-making, given that methods and forms of teaching are outdated, and teachers do not want to change anything (KARAMANOV, 2017).

The pedagogical activity in the museum aims to interpret, reveal the connotative meanings of the exhibits and convey these meanings to visitors. Understanding the inner essence of the mission begins with the question: why are exhibits stored and interpreted in general? The obvious answer is to develop society through the personal growth of citizens (UDOVYCHENKO, 2017).

The accessibility and openness of modern museum institutions, their value and information potential contribute to involving the public in interesting forms of intellectual and socio-cultural creativity, thus emphasizing their importance for the educational sector. In this regard, there is a need to analyze the state of using educational opportunities in the museum environment, clarify the contradictory points and find innovative ways to operate museums as multidimensional cultural and educational centers.

\section{Results and Discussions}

As a result of the study on socio-cultural processes of Ukrainian society, the authors have reason to believe that within the framework of developing museum pedagogy as an innovative scientific field and a unique psychological and pedagogical technology, the following positive trends are observed:

1) revitalizing museums with audiences of different ages;

2) creating interesting projects of interdisciplinary content;

3) developing original museum-pedagogical programs;

4) finding promising areas of constructive cooperation of museum institutions with educational institutions etc.

The paradigms of historical and cultural development of nations and peoples, world civilization, certainly, determine the qualitative changes in the current tasks of both cultural and educational institutions. First of all, the methodology of realizing functions of the museum, which is not only a source of additional knowledge but the civil, information, educational center of the cultural heritage working for the benefit of the person, changes. In the countries with 
more developed democracies, museum institutions are special socio-cultural institutions where, in addition to the cognitive and educational environment, social dialogue is formed. After all, without it, progress in the development of civil society and human self-consciousness is impossible. The museum, as an educational institution, must introduce a subject-subject model of communication, interpersonal, cultural-ideological and intercultural dialogue.

Despite the above positive achievements in the development of museum pedagogy, controversial issues have been identified regarding the implementation of the educational function of museum institutions. In particular, there are no systematic and purposeful educational and museum activities, integrity and professionalism in the development and application of interesting interdisciplinary projects and educational and museum programs. The practice shows that such software products are aimed mainly at children of primary school age and are limited to describing their actions, their occasional participation in joint activities, discussion of individual actions, comments on works of art. On the one hand, such cooperation is necessary and interesting. At the same time, this activity pays little attention to developing creative and critical thinking in students, their ability to solve problem situations and does not provide favorable conditions for cognitive interests, curiosity, creative imagination and fantasy. This is because the educational function of museum institutions is often realized not by a creative team of specialists but by individual amateurs, enthusiasts, associated with the purposeful support of museum pedagogy at the state level.

In Ukrainian society, it is traditionally believed that the field of museum pedagogy is the object of fundamental and applied research, mainly museum institutions, and therefore museum staff individually develop appropriate programmes for interaction with visitors. At the same time, O. Karamanov's opinion is relevant that, when developing author's lessons and excursions, it is important to seek professional help from subject teachers, freelance teachers, psychologists, researchers, whose subject of scientific interest is the material of a particular exhibition, and the use of interesting ideas, current museum-pedagogical technologies with the profile of a particular museum, the nature of the activity, the age of visitors and their motivation depend on the awareness and professionalism of the museum worker and the teacher, who act as intermediaries between the teaching material, students and museum exhibits (FILIPCHUK, 2018). Thus, an interesting museum-pedagogical program can be created only if considered the proposals of historians, museologists, teachers (educators, subject teachers), psychologists, culturologists, sociologists.

The well-known museologist Robert Berg considered the museum as a kind of dialogue between people divided in time and space. Therefore, when developing and implementing 
museum-pedagogical programs, it is important to take into account the following objectives of research activities of future professionals and, in particular, teachers in museum institutions: to acquaint with different types, profiles and types of museums and master certain skills of museum staff (storage, exhibition, restoration, research, educational, pedagogical activities); to study traditional (excursion, lecture, conversation) and innovative forms (virtual trips, theatrical performances, "strategies of visual thinking", "storytelling", "museum Web 2.0"); to find out the history of the museum (or museum room of the educational institution), its purpose and social role; to compile common descriptions-characteristics of museum exhibits; to provide assistance to museum staff in organizing excursions (BAZYL, 2008; SEMENOH; BAZYL; DIATLENKO, 2011).

In Ukraine, the first museums were created in the early $19^{\text {th }}$ century: the Mykolaiv Museum (1806), the Feodosiia Museum of Antiquities (1811), the Odesa Museum of Antiquities (1825), the Kerch Museum of Antiquities (1826), and the Lviv Museum of Art (1874). The main precondition for opening museums was the need to create an effective and original form of preservation of monuments of traditional culture.

The activities of university museums play a significant role in the study and research of historical phenomena and events (Archaeological, Zoological, Mineralogical), Museum of Fine Arts, Museum of Fine Arts at Kharkiv University, Museum of Antiquities, Numismatic and Zoological Museum at Kyiv University, Kyiv City Museum, Chernihiv Museum, Kherson Historical and Archaeological Museum, Katerynoslav Art Museum, Poltava Provincial Municipality Museum, Lviv Museum “People's Home”, Ternopil Museum of Local Lore. A historical and pedagogical analysis of the retrospective of the interaction of classical universities and museum institutions proves that educational activities of museum institutions intensified during the $19^{\text {th }}$ century - the first decades of the $20^{\text {th }}$ century, which contributed to developing pedagogical and classical education and approved the culturological and nationbuilding mission of museums in the educational and scientific space of Ukraine (VOVK, 2016).

Applying the results of museum pedagogy in the educational space, it is important to consider the historical features of museum policy. It is known that the museum business in the second half of the $20^{\text {th }}$ century was built on the principles of the then-dominant ideology. Scientific research, excursions, exhibitions, methodological developments, bibliographic descriptions and other activities were based on the established party doctrines. Indeed, the guidelines "The main stages of preparation for the tour", issued by the Ministry of Culture of the USSR and the State Historical Museum of the USSR in 1983 and 1989, show that tours are an effective means of communist education; an excursion is one of the forms of propaganda, 
which determines the introduction of such requirements as party affiliation. Party affiliation (noted in the document) is one of the basic methodological principles of Soviet museum studies, expressing the ideological orientation of museums, their position in the social struggle" (MINISTRY OF CULTURE OF THE USSR, 1980).

Although some attention was also paid to the principles of scientificity and inseparability of connection with life, it was "high ideological content, coverage of specific facts from the standpoint of modern science, the practice of communist construction" (Ministry of Culture of the USSR, 1980) that defined the essence of museum work. Such a niche helped to form cognition, emotionality, imagery, accessibility of excursion methods, museumeducational activities. The ideological component, which contained the relevant "scientific" explanations and justifications, was at the heart of assessments of the effectiveness of museum institutions. Quite often, the high "ideological" content was based on the same deep "scientific" level.

Museum policy was structured in such a way that museum exhibits and cultural heritage in various dimensions were necessarily linked to the practice and prospects of communist construction. Indeed, the training and retraining of museum staff were formed following the profile areas, status, identity of visitors and the audience, so that the content of the presentation was primarily accessible to perception. Therefore, in most cases, the "dialogue" between museum workers, teachers and visitors took place from a propaganda perspective. It was in this niche that the methodology of museum work was improved. Knowledge, emotions, imagery, accessibility and guides' persuasiveness served primarily ideological principles, propaganda, the then political imperatives, which, as a rule, were not consistent with the truth, historical truth or scientific laws. Reliability, scientific correctness and objectivity, passing through the sieve of ideologies and class theories, were transformed into superficial, erroneous ideas, concepts, false views of the world, man, nature, society. "Ideology" became a benchmark, according to which attempts were made to creatively implement the "scientific" foundations, approaches, to develop theoretical principles of museum studies. It most significantly influenced the essence of the museum business, as well as the level of its educational and cognitive significance.

The museum policy developed by the Ministry of Culture of the Ukrainian SSR in the 1980s formally reflected a certain logic and adequacy of approaches. For one, it is difficult to deny or prove the unfoundedness of excursion methods in museums, which included such important aspects as forming and defining themes of excursions; preparing a museum tour; holding a museum tour; improving the quality of the museum tour; introducing the best 
practices. Museum institutions in different countries have operated and are operating under similar parameters. Similar areas of work and the nature of the requirements are laid down in modern Ukrainian museum studies because there is certain universal manufacturability of processes. Public needs, public tasks, human needs and interests will always encourage the emergence not only of new museum institutions but also the continuing development of new exhibitions, museum tours, which is one of the indicators of the effectiveness of museum activities in a particular country, regionally and nationally.

The new thematic orientation is also formed not spontaneously or narrowly-subjectively but corresponds to certain motivational aspirations. Again, they are consonant with the classical stability of the reasons that determine the development of museum work in its research, educational, cognitive and educational dimensions. Moreover, these manifestations have certain patterns. First, the inquiries, social and individual tastes, and the interests of citizens regarding their views of the world and of "themselves" are always considered (to one degree or another). Secondly, the interests of specific nation-states and societies, the nature of their political system, historical and cultural tradition and ideological motives have a great influence on the content of the museum sphere and reforms in museum activities.

Such factors act as a unified pattern in the environments of different socio-political regimes - from authoritarian to democratic and humanistic. At the same time, ideologies, values and ideals characterizing the essence of the socio-political system, its moral, ethical and historical image are always invested in different ways. The ways of civilizational progress were built depending on the values on which the public consciousness was based, how objectively the transformation of the past took place, which shaped the existence and prospects of the future.

The human historical and cultural heritage of spiritual and material nature, including that located in the niche of the museum environment, contains a huge unique potential of cognitive, educational content that can affect the architecture of society, mentality and culture of human consciousness as a productive, progressive, humanistic dimension and promote the creation of evil, focusing on the wrong ways of their knowledge of the world. The practice has shown that the uniqueness of the perception of heritage and achievements of mankind in the fields of culture, science, technology, economic and industrial activities and the development of Nature is determined primarily by public order, as well as the level of ethical responsibility, humanity and democracy.

Indeed, if a person is only "knowledgeable" and unethical, his or her arrogance and excessive egocentrism will make it impossible to have a true vision of his or her place in the 
hierarchical ladder of the Nature of Being. It is also inappropriate when a person is "ignorant", humiliated, deprived of freedom. Albert Schweizer, the Nobel Peace Prize winner in 1952, was right about this. The prominent philosopher, psychologist and sociologist of the $20^{\text {th }}$ century Erich Fromm in his work "Have or Be?", professing the philosophy of universal humanism, recalled what Schweizer said,

man has become a superman... But the superman, endowed with superhuman strength, has not yet risen to the level of the superhuman mind. The more its (human) power grows, the poorer it becomes... Our conscience must wake up from the fact that the more we become superhumans, the more inhuman we become (FROMM, 2012).

This is especially evident in the conditions of despotism when this role is completely taken over by dictators, autocrats, inhumane rulers, which characterized the situation in stateless Ukraine.

Today, the agenda of modern civilization, written (ideally) under the principles of sustainable development, should be formed not based on the assertion of human hegemony as an authoritative "ruler" of the world over another person or nature but its ethics and humanization. After all, the latest knowledge or mastery of modern technologies is not always a factor of progress and productive results that serve the public good. The harmony of "being" requires a much deeper "development" of the cultural riches of mankind, specific peoples and ethnic groups. Knowledge, information and competencies can sometimes be transformed into ingenious ideas, discoveries, theories, technological breakthroughs, although it is not enough for the nature of social life. Everything "human" must be endowed with a moral principle, humanized, using value categories, feelings, noble motives, emotions, irrational sensuality of perception of the world, conscience, ideals. Without this, not only progress but also survival is impossible.

Therefore, this general civilizational need must become a regularity in approaches to the semantic functionality of those areas, institutions that play the role of cognitive, cultural, scientific and educational nature. The museum environment is just such an optimal niche in which these functions are performed. However, each educational, cultural and scientific system operating in specific social, political and ideological models, forms the basic foundations of museum policy quite uniquely, following the national specifics and social structure. Its main goals and objectives are often endowed with essentially radically different motivations, meanings, tasks, even under the conditions of a short period of history. The same European cultural and educational space, in particular at the level of museum affairs and against the 
general background of certain structural homogeneities and identities, was also characterized by essential semantic opposites.

The study of the content and forms in the field of museum studies or museumpedagogical education showed several similarities in approaches to museum work in Ukraine (the 1950-80s) and European countries related to Western European democracy. However, the semantic analysis showed that it was most likely of a general structural, methodological nature. In fact, in the Ukrainian SSR, as in many European countries, after the Second World War, museum policy began to receive more and more attention. The expansion of excursion topics, the creation of new types of museums by profile, the improvement of bibliographic work, an intensive study of new sources and the creation of new expositions and exhibitions, the compilation of new excursion routes based on researched objects and the significant improvement of excursion methods, the introduction of new texts, methods and techniques were characteristic of the museum and pedagogical activities of different countries and systems.

However, completely different values, ideologies, political regimes that existed and were implemented in specific countries determined the museum policy, the nature of cultural, educational, educational activities of museum institutions, for which targets were prepared and the theme was outlined. Such an ideologically organized approach was especially characteristic of state formations that professed communist-bolshevik ideology. It is significant that in the most ingrained conservative forms, these ideologues were implanted and preserved in the USSR, particularly in Ukraine. At a time when communist practice and politics in the late 1980s in Central Europe were finally collapsing, museum policy in the Ukrainian socio-cultural environment continued to try to assert rudimentary ideas, principles and methodology. The normative documents, instructions and methodological recommendations for museum tours prepared at the governmental and ministerial levels at that time stated the following: "in determining the purpose of the tour, it is necessary, first of all, to point out the importance of this topic in communist education" (MINISTRY OF CULTURE OF THE USSR, 1989).

The subject of excursions in each museum is determined by its profile, requests of visitors and actual tasks of ideological work. Museums, like other ideological institutions, are designed to promote the formation of a scientific Marxist-Leninist worldview, class consciousness, socialist and proletarian internationalism. When forming the topics, museums had to consider the requests of educational institutions (secondary schools, vocational schools, technical schools and universities), as well as training programs in the network of political education. Despite the fact that in 1989 there was a radical worldview revolution in the world (Europe) and there were processes of national revival and the struggle for state independence 
in Ukraine, the Ministry of Culture of the USSR continued to keep the museum business in the ideological blinds of the totalitarian regime.

Such tendencies in the organization of museum affairs proved that the state ideology was the basis of museum studies, the content of educational and educational activities. It was a determining force not only in the spiritual, intellectual organization of society, its educational, cultural, scientific institutions but also for professional development, worldviews, creativity of the individual. Critical thinking and views on the world, social problems and challenges, human rights were not only not supported but also severely persecuted if attempts were made to disagree with established ideological dogmas, existing social practices and public policy.

An authoritarian, ideologically zombie, semi-true museum policy was produced in a totalitarian atmosphere. In Ukraine, its task was primarily to continue the process of deUkrainization. This was served in particular by signing the 1984 Order of the Ministry of Culture of the USSR on the translation of records in all museums of Ukraine into Russian.

As for the content, regardless of what types of museum objects were presented in exhibitions, thematic exhibitions and stands, a necessary condition for their presentation was (as noted in regulations) "the study of the classics of Marxism-Leninism, the CPSU Programme, party congresses and plenums of the Central Committee of the CPSU, government decisions and other documents, as well as socio-political literature", paying special attention to the works of the classics of Marxism-Leninism and the fundamental party and state documents" (MINISTRY OF CULTURE OF THE USSR, 1989). All museum objects (material monuments, relics and memorial materials; documentary monuments; archival materials; monuments of fine arts etc.) that were the objects of excursions passed through the "ideological-scientific" Marxist-Leninist "X-ray". Only in this version of the show and presentation, they were offered to the visitor, tour group, audience. If the "heritage of Marxism" was rather difficult to attach to the main objects of the museum display, which were represented by significant rare monuments and materials, additional museum objects were necessarily sought to strengthen the ideology of the supporting exposition complexes.

For each museum institution and museum policy in general, the main guidelines were the ideological foundations of communist doctrine in its most brutal dimension of Russian Bolshevism. Although, starting from the central state museums and ending with school, formally all scientific-methodical, educational-methodical and cognitive developments and recommendations provided clarity of the defined subjects, the purposes, tasks of museum expositions and excursions, the main and secondary objects of attention, routes, methodical receptions, shows, presentations and stories. However, all plans and activities were subject to a 
single methodological goal, that is, the focus on communism (Bolshevism), internationalism (Russianness), "humanism" (Mankurtism). In the territories where Ukrainians had lived since ancient times, this ideology and practice was especially determined to eradicate the people, destroying the historical truth, its national culture, language, faith, genetic memory, the values of state aspirations.

Having won Independence, the Ukrainian state today must do everything to ensure that the main mission of Ukrainian museums, namely, the education of citizens based on national and world historical and cultural heritage, has become an important factor in nation-building. In recent years, the interaction of museums and educational institutions on the issue of nationalpatriotic education has intensified. The use of museum-pedagogical tools in the formation of patriotic qualities of school and student youth is becoming a topical issue for modern Ukrainian museum pedagogy. Conferences, seminars, lectures, workshops and training of teachers and museum workers in the system of methodological associations provide an opportunity to present, study and master new and innovative technologies used by museum pedagogy in the practice of the modern school. Pedagogical, cognitive and educational tasks have now actualized the problem of developing civic and patriotic qualities of the individual, which is important for the state, society and individuals. Such a vector in the educational process and the system of interaction of the "school-museum" model is undoubtedly connected first of all with Russia's aggression against Ukraine, the struggle of the Ukrainian people for their independence, sovereignty and territorial integrity. Such forms and directions in the system of museum pedagogy as the introduction of museum pedagogy in the educational process, the effective use of the potential of museums, especially historical and local lore, the training of teachers and museologists to perform specific educational tasks and the introduction of experience of interaction between school, museum, public spaces, research and creation of mini-museums have become sufficiently popular for the quality of the educational process. Practically, museum pedagogy becomes an innovative component of school development since the museum environment has unique knowledge and educational resource and, most importantly, enables the development of abilities, motivates the individual towards selfdevelopment, finding and learning new information from primary sources, artefacts.

Both traditional and usual forms and methods of work, as well as the content of exposition work in the educational process acquire new meanings and tasks. After all, the question of implementing a qualitatively new Strategy of national-patriotic education, especially for young people, has arisen with all the urgency of society and the state. The interaction between education and the museum today actualizes "the purpose of educating a 
citizen - a patriot of Ukraine, affirming love for the Motherland, the national heritage of the Ukrainian people, following the best examples of courage and victory of freedom and independence fighters of Ukraine from the historical past and defenders sovereignty and territorial integrity of the state in the fight against external aggression" (Strategy of nationalpatriotic education of children and youth for 2016-2020). New realities that have emerged as a result of Russia's aggression cause the emergence of new paradigms of knowledge, worldview, scientific-historical and educational nature in the content of education, national museum studies. The changes in exposition-demonstration themes, educational plans and programs and museum policy are focused on solving the most important task, that is the qualitative transformation of national consciousness, psycho-mentality of Ukrainians, their patriotism and citizenship concerning Ukraine. To win the competition and struggle for the preservation and strengthening of Ukrainian national identity, it is necessary to overcome the "presence of imperial-totalitarian rudiments in the public consciousness due to the destruction of Ukrainian spiritual and cultural heritage and historical memory and differences in perceptions of the historical past, including totalitarian era, famines and political repressions" (Strategy of national-patriotic education of children and youth for 2016-2020).

\section{Conclusion}

Museum pedagogy needs to improve the educational activities of departments and research laboratories, museum pedagogical and research centers, which would stimulate the use of innovative pedagogical technologies with the involvement of museum collections, substantiate national and foreign experience in using cultural museum heritage to educate and strengthen the nation. This issue requires a level of national and state attention to museum pedagogy, museum studies and educational efforts to become effective tools. The following should be done:

- To regulate the legal sphere of national-patriotic education;

- To build a unified approach (throughout Ukraine) of the methodological and terminological plan;

- To develop universal value dimensions to the content, processes, subjects, their responsibilities and authorities;

- To improve the training of human resources in the field of museum pedagogy, coordination and material base. 


\section{REFERENCES}

BAZYL, L. O. Features of the organization of ethnographic practice in the professional training of teachers of vocabulary. Ukrainska literatura v zahalnoosvitnii shkoli, 12 , 34-37. 2008.

BELOFASTOVA, T. Yu.. Museums in the cultural space: an evolutionary approach. Bulletin of the State Academy of Management of Culture and Arts, 1, 53-57. Millennium Publishing House. 2010.

DUDAR, O. V. Actuality and perspectives of museum pedagogy. Proceedings from the VI Annual All-Ukrainian Scientific and Practical Conference: Research of young scientists in the context of the development of modern science. Kyiv. 2016.

FILIPCHUK, N. Museum pedagogy in the optimization of the cultural and educational process. Dukhovnist osobystosti: metodolohiia, teoriia i praktyka, 2 (77). Kyiv. 2017.

FILIPCHUK, N. Museum pedagogy and education of the nation. Molodyi vchenyi, 3 (55),137-142, 2018.

FROMM, E. To have or to be? Zaporizhzhia: Big Press. 2012.

KAMINSKA, V. Museum pedagogy in the practice of modern CEE. Volyn Museum Bulletin, 5, 50-53. 2013.

KARAMANOV, O. V. Museum pedagogy and STEAM education: new opportunities for innovation. Proceedings from Fifth Scientific and Practical Conference: Museum pedagogy problems, present, prospects. Kyiv-Pechersk National Historical and Cultural Reserve. Kyiv. 2017.

Ministry of Culture of the USSR Methodical recommendations on the main stages of excursion preparation. Kyiv, p. 5. 1980.

Ministry of Culture of the USSR. Methodical recommendations on the main stages of excursion preparation. Kyiv, p. 5, 1989.

SEMENOH, O. M.; BAZYL, L.O.; DIATLENKO, T.I. The professional practice of a teacher-vocabulary. Luhansk: Knowledge. 2011.

State National Program “Education” Ukraine of the 21 ${ }^{\text {st }}$ century. Kyiv: Raduga. 1994.

The strategy of national-patriotic education of children and youth for 2016-2020. Decree of the President of Ukraine of October 13, 2015, No 580 / 215. Available:

$\mathrm{http} / / \mathrm{www}$. lib.ru/politolog/lebon/psihologia.txt

UDOVYCHENKO, I. Museum pedagogy: theory and practice. Kyiv: Logos. 2017. 
VOVK, M. Development of academic culture in the scientific and educational space of Kharkiv University (the second half of the $19^{\text {th }}$ century - the early $20^{\text {th }}$ century).

Pedahohichni nauky, 66, 140-149. 2016.

\section{How to reference this article}

NATALIIA, F.; YARINA, K.; LUDMILA, B.; VALERIY, O.; MYROSLAVA, V.; GALINA, Z. Museum pedagogy in education: educatinal, historical, and pedagogical aspects. Revista on line de Política e Gestão Educacional, Araraquara, v. 25, n. esp. 3, p. 1844-1859, Sep. 2021. e-ISSN: 1519-9029. DOI: https://doi.org/10.22633/rpge.v25iesp.3.15596

Submitted: $20 / 03 / 2021$

Required revisions: 05/06/2021

Approved: $12 / 07 / 2021$

Published: 01/08/2021 